\title{
Simbologias medievais n'A Pedra do Reino
}

Cintya Kelly Barroso Oliveira ${ }^{1}$

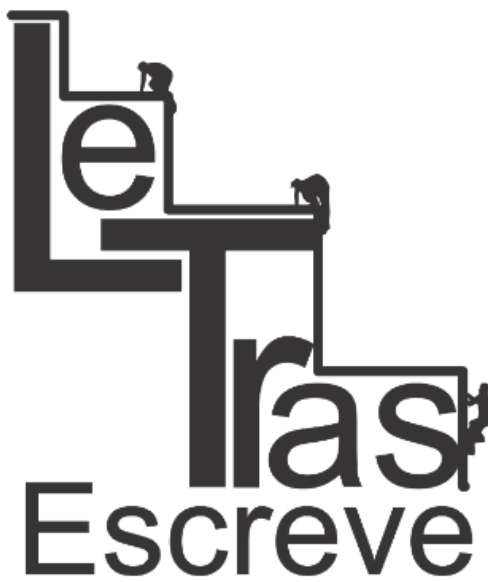

(ISSN 2238-8060)
Resumo: O Romance d'a Pedra do Reino e o Príncipe do Sangue do Vaie-Volta, livro de Ariano Suassuna, é o corpus deste trabalho. A fim de buscar entendimento da simbologia risível da narrativa, a investigação se pauta nas vertentes temáticas da tradição religiosa e da profana decorrentes do medievo. No trabalho nos propomos a apresentar algumas aproximações entre a cultura brasileira contemporânea e a Idade Média, verificando, especificamente, os resíduos, ou melhor, o que restou, permaneceu no romance, do imaginário mediévico. $O$ método de investigação é o proporcionado pela Teoria da Residualidade, de Roberto Pontes, que tem como premissa estudar os resíduos de um passado próximo ou distante, os quais permanecem de um tempo em outro numa narrativa ou cultura. Segundo os pressupostos dessa teoria, os indicadores culturais estão presentes na mentalidade de uma sociedade sob forma cristalizada, e decorrem da hibridação cultural havida entre o Brasil e os demais povos.

Palavras-Chave: A Pedra do Reino. Sagrado. Profano. Resíduo

Abstract: The Novel Stone of the Kingdom and the Prince of the Bloodand-Go Round, by Ariano Suassuna, is the corpus of this paper. In order to try to understanding the humorous symbolism of the narrative, this research is based on the thematic trends related to religious and profane traditions arising from Medieval Times. This paper aims to present some similarities between the Brazilian culture and the Middle Ages, especially verifying the residues, that is, what has remained from that imaginary period in the novel. The research method used was Roberto Pontes's Theory of Residuality, which is based on the study of residues from a near or distant past, which remain for some time in a certain text or culture. According to this theory, the cultural indicators are present in the minds of the members of a society in a crystallized way and these indicators are originated in the cultural hybridism between Brazil and other peoples.

Keywords: Stone of the Kingdom. Religious. Profane. Residue.

\section{1. À guisa de introdução}

O processo de escrita d'O Romance da Pedra do Reino, do escritor Ariano Suassuna, dentre as inúmeras possibilidades de

1 Doutoranda em Educação da Universidade Federal do Ceará - UFC; Mestre em Literatura - UFC; Especialista n'O Ensino de Literatura - UECE; Licenciada em Letras - UFC; Graduanda em Pedagogia - ESTÁCIO/FIC; Professora da Educação Básica e Superior; Integrante do Núcleo de Educação, Currículo e Ensino - LECE/UFC e do Grupo de Pesquisa AgoStos - Alimentação, Gosto e Saberes - UFC. Email: ckletras@yahoo.com.br

https://periodicos.unifap.br/index.php/letras

Macapá, v. 6, n. I, Io semestre, 2016. 


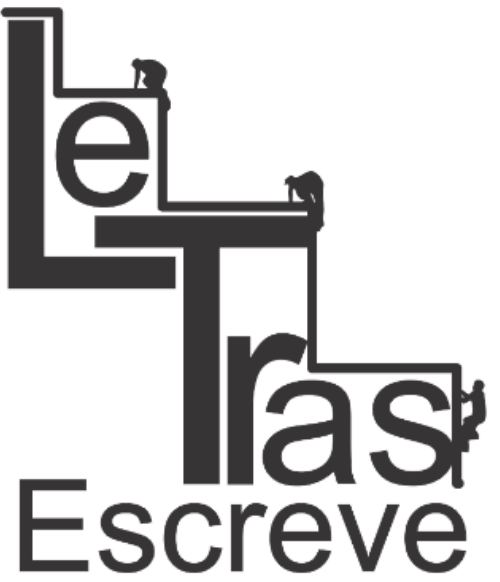

(ISSN 2238-8060) análise, conta com um olhar sobre o passado devedor de uma visão medieval remanescente no Nordeste brasileiro. As histórias que compõem o romance de Ariano Suassuna são narrativas que se nutrem do imaginário do povo nordestino e estão concretizadas em seus mitos, lendas e superstições. No caso do escritor paraibano, a matéria-prima ficcional, provém do Romanceiro popular, das festas populares, do repertório etnológico nordestino e das histórias ouvidas pelo autor durante a infância.

É notório que a obra suassuniana incorpora com propriedade as referências clássicas, medievais e populares. O texto do autor paraibano se alicerça nas referências à literatura universal e à brasileira, através de uma escrita residual proveniente de outras. 0 processo de composição textual formado por resquícios de tempos, culturas e povos anteriores é possível, pois "em literatura e cultura nada é original, tudo é residual" (PONTES, 2004). A ideia é mostrar as componentes fundamentais da escrita de Suassuna, cujas raízes d"além-mar foram incorporadas ao patrimônio cultural do espírito coletivo nordestino, bem como analisar de que forma esses resíduos mediévicos ainda são latentes.

Das fontes criadoras do dramaturgo paraibano vale salientar a presença literária do teatro medieval, bem como as referências constantes à picaresca e à comédia dell"arte. Todo o percurso romanesco é ditado sob um viés risível e irônico, sendo por este meio, atingida a resolução estética e humana proposta por Suassuna. O sertão d'A Pedra do Reino é antes um mito, teatro sagrado, circo popular, uma grande metáfora da vida. O quadro folclórico do romance é endossado por menções relativas ao Romanceiro Popular do Nordeste, inclusive, a literatura de cordel, a xilogravura e a heráldica. Essas referências não constituirão análise detida neste trabalho, servirão para mencionar a vinculação do romance à perspectiva armorial, cujo uso é pressuposto para compor a arte proposta pelo movimento. Tais aspectos caracterizam

https://periodicos.unifap.br/index.php/letras Macapá, v. 6, n. I, Io semestre, 2016. 


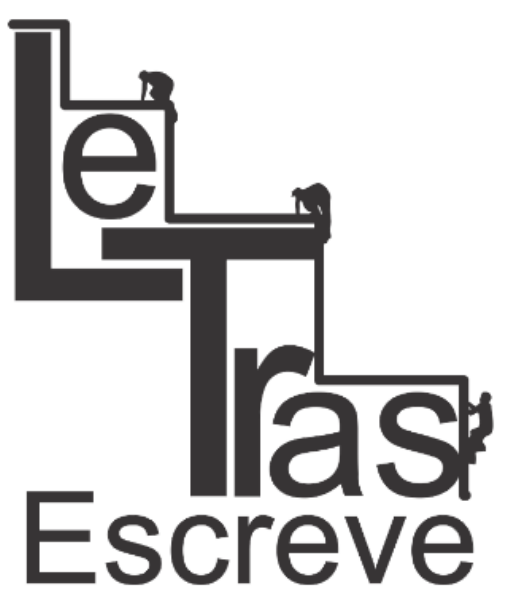

(ISSN 2238-8060) o projeto artístico armorial do autor Ariano Suassuna, termo este proveniente do Movimento de 1970.

Há, em A Pedra do Reino, componentes europeus, brasileiros, nordestinos, políticos, religiosos, morais e ideológicos, possibilitando diversos modos de análise e de leitura, o que dificulta sua classificação em gênero e em escola literária. Ao contar sua "desaventura" o narrador Quaderna traduz uma visão literária e mítica do sertão. Muitas vezes comparado à narrativa cervantina, o romance realiza o mesmo procedimento narrativo de sonho e loucura. Porém, o diferencial está no fato do narrador suassuniano apresentar a consciência de narrar uma obra literária, sem se preocupar com o realismo ou com a realidade histórica. A narrativa é alimentada por citações que a nutrem, dando-lhe um caráter de veracidade. Ao recorrer a obras alheias, Quaderna constrói seu castelo literário no espaço do sertão de Taperoá. Fazendo do sertão um mito, ele deforma a realidade a seu favor, convertendo o espaço em protagonista do romance e partícula do seu universo.

\section{O medievo presente no romance}

Ressaltamos que nossas referências de análises foram, em sua maioria, retiradas da dramaturgia da Idade Média, pois, tratando-se de mentalidade e não da estrutura de gêneros, as remanescências são mentais e não textuais. Com efeito, é possível que respirem nos folhetos da narrativa a mesma mentalidade usada pelo autor em suas peças cômicas, pois, desejamos investigar se Ariano representa em sua ficção as mesmas propostas da dramaturgia da Idade Média. O inconsciente coletivo utilizado no literário pelo escritor constitui aporte residual, já que se pauta no resgate das estruturas mentais e comportamentais de um povo mais antigo, respirando nas linhas do escrito contemporâneo. Pelo mesmo modo, esperamos que a contribuição desse trabalho se dê também porque destacamos uma proposta nova no concernente à

https://periodicos.unifap.br/index.php/letras Macapá, v. 6, n. I, Io semestre, 2016. 


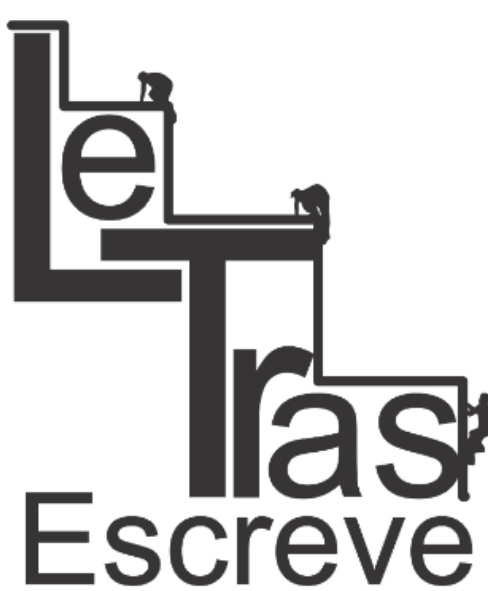

(ISSN 2238-8060)

análise literária, ou seja, a utilização da Teoria da Residualidade. Referimo-nos ao modo de entender a mentalidade de uma época anterior, sob forma de resíduos cristalizados na memória coletiva nacional oriundos do processo de hibridação cultural por que passou o Brasil, o Nordeste especialmente.

A Pedra do Reino é uma representação literária muito clara da simbologia e da imagética medieval remanescente no Brasil. A obra é construída por várias narrativas que se interpenetram em movimento de vai-e-volta, e unidas num único nó. Os componentes ibéricos mediévicos refletidos na memória coletiva vieram à tona por meio de substratos mentais. Ora, se a identidade do Nordeste é feita de uma miscigenação, de uma convergência de culturas, então, o produto cultural decorrente é uma cristalização, e pode ser explicado pela hibridação cultural por que passou o Brasil, em especial o Nordeste.

A cultura nordestina provém do processo histórico da colonização, recebida que foi de Portugal, juntamente com as estruturas sócioeconômico-culturais ainda muito próximas das medievais e da ideologia dominante na metrópole. A escolha do estudo da obra suassuniana sob o prisma do medievo se dá por acreditarmos em remanescências daquele momento histórico na literatura do escritor paraibano. O esteio mediévico pode ser facilmente recuperado a partir da mentalidade da sociedade ficcionalizada por Suassuna.

Se determinados procedimentos conscientes de fatura artística, por parte do autor, tratar de referências no plano do texto, podem ser intitulados de intertexto com a Idade Média, como por exemplo, as citações literais ou pouco modificadas dos folhetos do Romanceiro, procedimento esse armorial. Porém, embora citados pelo viés intertextual, o imaginário e o espírito fantástico desses folhetos, em sua maior parte, permitem ser entendidos como um processo inconsciente presente no modus vivendi da região Nordestina, foco esse aproveitado pelo escritor em sua obra. Além 


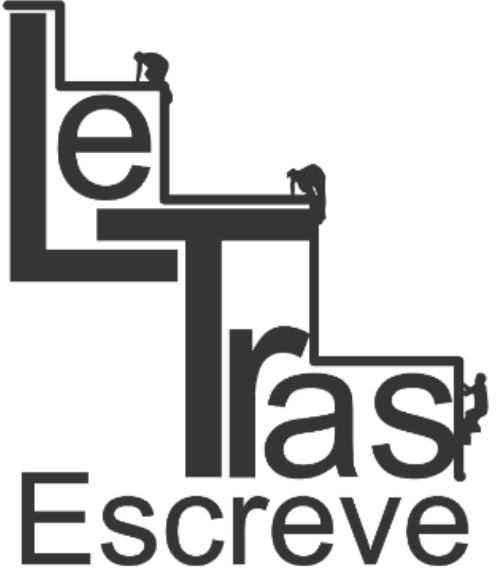

(ISSN 2238-8060) de um passado visível inserido no romance, existe um outro a ser recuperado em suas páginas por meio da mentalidade e da memória coletiva.

O argumento do Romance d'A Pedra do Reino é difícil de sublinhar porque esta é uma narrativa em miscelânea, na qual várias vozes ressoam. O nó em sua estrutura, proveniente de uma trama caleidoscópica, não é desatado pelo narrador Quaderna. Ao contrário, essa é a principal arma do protagonista a fim de retardar o desenlace do mistério que se propõe a contar. Para alguns críticos da obra suassuniana, esta narrativa confunde-se com a história pessoal do autor, ao mesmo tempo em que, por se tratar de um depoimento do narrador Quaderna ao Corregedor da região, adquire igualmente a face de depoimento-denúncia à nação brasileira.

O autor utiliza os mesmos fatos do seu drama pessoal, manipulando literariamente o Romanceiro do Nordeste e as festas populares da região. Ariano faz uso da técnica vinculada à tradição dos romanceiros medievais, além de referências à epopeia, ao folhetim, à cavalaria, à picaresca, só para citar alguns dos gêneros presentes na narrativa, embora, alguns deles, não sejam referidos por nós ao longo desta análise.

Quanto à classificação do gênero d'A Pedra do Reino, não há um senso único por parte da crítica. É um romance, de acordo com alguns, ou, se preferirmos, uma epopeia, ou poema em prosa. É constituído por cinco Livros, sendo que, no primeiro deles, é contada, depois de uma invocação à Musa Sertaneja, a chegada de uma cavalgada que traz a Taperoá o "Rapaz do-Cavalo-Branco", fato desencadeador da prisão do narrador. Quaderna é acusado do envolvimento na morte de seu padrinho Pedro Sebastião, pai do primo Sinésio, o Rapaz do- Cavalo-Branco. Ocorre que este desaparece misteriosamente no dia da morte por degolação de seu pai e retorna, segundo os fatos narrados na obra, como a reencarnação de Dom Sebastião, rei de Portugal. Por fim, no derradeiro folheto do Livro final, há o relato do sonho de Quaderna

https://periodicos.unifap.br/index.php/letras Macapá, v. 6, n. I, Io semestre, 2016. 
sendo consagrado pela Academia Brasileira de Letras, em cerimônia régia, como "Gênio da Raça Brasileira", sagração esta sonhada pelo narrador e munida pelo desejo de imortalizar-se escritor de uma "obra literária modelar e de primeira classe", que só poderia ser escrita por ele mesmo, um gênio literário e decifrador.

\section{Da tradição religiosa}

Devido à remanescência residual da arte medieval na cultura nordestina, a obra de Ariano Suassuna se prende tanto ao profano quanto ao sagrado, quando incorpora aspectos do Auto e do Riso, além de utilizar recursos dramáticos dos mistérios, dos milagres e das moralidades. O religioso é presente em seus escritos, valendo identificar n’A Pedra do Reino, as aproximações mentais entre o imaginário ibérico e o sertanejo suassuniano. A tradição religiosa presente na obra de Suassuna é fruto de indicadores culturais préexistentes na mentalidade nordestina, sob forma cristalizada, decorrentes da hibridação cultural havida entre Portugal e Brasil. De forma mais específica, foi percebida por nós na obra vicentina, na medida em que esta mentalidade se nutre, tal qual no dramaturgo português Gil Vicente, de rituais litúrgicos próprios da Idade Média.

Partindo do pressuposto de haver o teatro medieval surgido (ISSN 2238-8060) da Missa, a ilustrar passagens de liturgia bíblica, o medievo criou um tipo de teatro cuja pretensão é narrar toda a história do mundo de acordo com a perspectiva cristã, a qual, como sabemos, é voltada para os magnos eventos sacros: a Paixão de Cristo e o Natal. É possível apontar os resíduos do medievo decorrentes do teatro desse período em $A$ Pedra do Reino. Isto posto, é coerente, por parte do pesquisador, o reconhecimento de indícios dramáticos medievais encobertos no romance. Acreditamos que os aspectos do teatro mediévico respiram na prosa do autor paraibano, embora a narrativa não utilize formalmente a estrutura teatral. Cabe esclarecer que o objetivo desta análise não é a investigação da estrutura de 


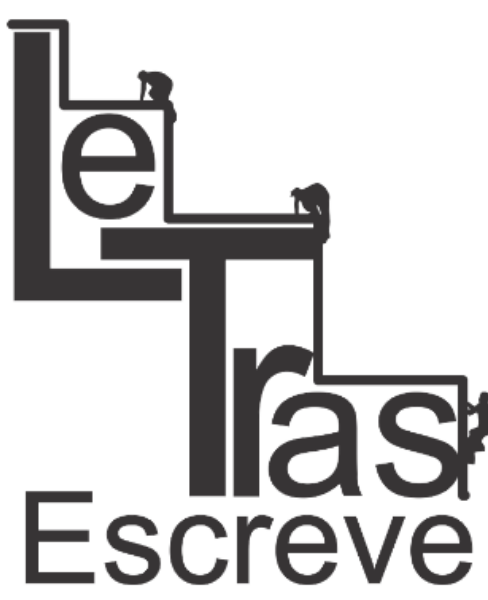

(ISSN 2238-8060) gêneros, mas a do imaginário devedor da dramaturgia medieval. $\mathrm{O}$ enfoque d'A Pedra do Reino como drama também é admitido por Maximiano Campos ao lê-la como drama da nossa própria condição, porém, sem a referência específica ao teatro mediévico: "não limitou o mundo à visão do Sertão nordestino, mas, através dessa visão de criador, fez do Sertão um palco gigantesco onde são representados, através de seus personagens, os dramas da condição humana" (CAMPOS, In: SUASSUNA, 2007).

A cultura sacra portuguesa que veio das naus representando e encenando o Corpus Cristi e a festa do Espírito Santo ainda hoje pulsa no Brasil e está presente nas comemorações religiosas, como por exemplo, As Santas Missões, a festa de São Sebastião, a Paixão de Cristo, o Dia de Finados. No Nordeste e em outras regiões os temas religiosos foram transferidos às festas populares, aos reisados, às cheganças, ao Bumba-meu-Boi, às Cavalhadas e o fogaréu de Minas e de Goiás.

No Brasil, a Cavalhada como representação dramática foi introduzida, sob autorização da Coroa, pelos jesuítas com o objetivo de catequizar os gentios e escravos africanos, mostrando nisto o poder da fé cristã. Por todo o Brasil encontramos as Cavalhadas sendo representadas, em diferentes épocas. Essas festividades residuais são apenas alguns dos exemplos, do religioso residualmente aparecendo em festividades no Brasil, provando, dessa forma, a cristalização de culturas tão antigas no imaginário brasileiro. Se essas manifestações culturais são tão fortes na cultura brasileira, como não estariam no romance de Ariano? Na narrativa, a presença delas é principalmente expressa em relação às Cavalhadas. Diversas vezes o narrador afirma a importância delas em sua vida desde a infância. Quando criança, o narrador ia com tia Filipa à missa de domingo na vila e depois assistiam a esses espetáculos. Segundo Quaderna, eram de importância capital em sua vida, o fragmento abaixo descreve os componentes da Cavalhada a qual o protagonista se refere:

https://periodicos.unifap.br/index.php/letras Macapá, v. 6, n. I, Io semestre, 2016. 


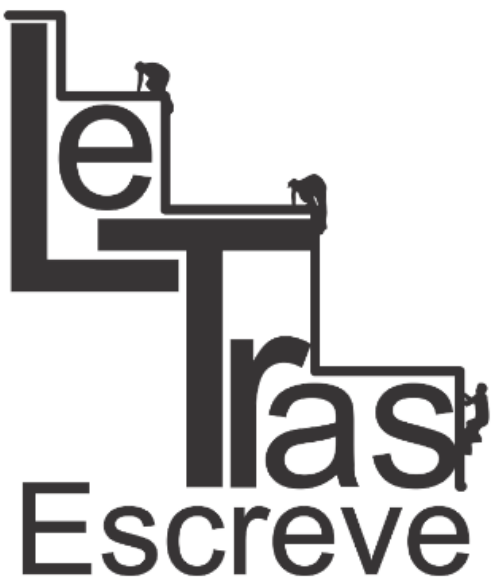

(ISSN 2238-8060)

Havia vinte e quatro Cavaleiros. Doze deles representavam os Doze Pares de França do Cordão Azul, e os outros doze, os Doze Pares de Franca do Cordão Encarnado. Havia, portanto, um Roldão do azul e outro do encarnado, de modo, que, apesar de serem vinte e quatro os Cavaleiros, aqui os Doze Pares de França eram realmente doze, a saber: Roldão, Oliveiros, Guarim de Lorena, Gerardo de Mondifér, Gui de Borgonha, Ricarte de Normandia, Tietri de Dardanha, Urgel de Danoá, Bosin de Gênova, Hoel de Nantes, o Duque de Nemé e Lamberto de Bruxelas (SUASSUNA, 2007, p. 99).

De acordo com a passagem podemos perceber a semelhança dos rituais encenados no sertão com a tropa de Carlos Magno durante a dinastia carolíngia. Essa permanência se deu por meio da oralidade e do imaginário sertanejo devedor de tempos remotos. Outro episódio descrito no romance ocorre quando Quaderna, já adulto, ainda guarda na lembrança os efeitos da simbologia das Cavalhadas assistidas na infância e, por isso, sonha em tornar-se rei e cavaleiro.

Minha vida, cinzenta, feia e mesquinha, de menino sertanejo reduzido à pobreza e à dependência pela ruína a fazenda do Pai, enchia-se dos galopes, das cores e bandeiras das Cavalhadas, dos heroísmos e cavalarias dos folhetos. Assim, quando agora me acontecia evocar os acontecimentos da Pedra do Reino, o que eu via eram os Pereiras, como uma espécie de Cavaleiros Cristãos do Cordão Azul, assediando e assaltando o Reino criado e defendido pelos Reis Mouros do Cordão Encarnado da família Quaderna. Sonhava em me tornar, também, um dia, Rei e Cavaleiro, como meu bisavô. Não para degolar os outros, mas para conquistar rosa e sete Princesas, queimando sete coivaras e abrindo, ainda, a broca dos cercados dos outros, pelo direito real de "dispensar" todas as donzelas do Reino em sua primeira noite de casadas (SUASSUNA, 2007, p.100).

Com efeito, a vida de sertanejo simples do narrador era enfeitada pela leitura dos folhetos e pela imagem das Cavalhadas assistidas no passado e no presente vivenciadas. Quaderna, espertamente, queria, como vimos no excerto, o reinado imaginoso para se apossar da ingenuidade das moças da vila, tal como fazia Dom João, o Execrável. Outra referência às Cavalhadas ocorre, 


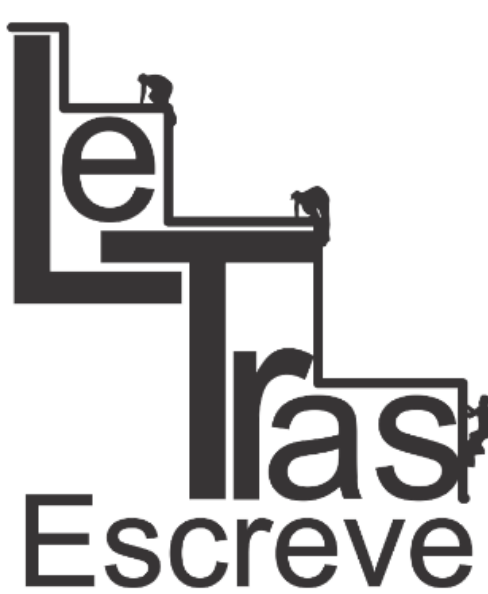

(ISSN 2238-8060) quando, Quaderna organizador desse tipo de festividades na vila, elegia seus irmãos bastardos para membros da "Guarda-de-Honra": "Meus doze irmãos bastardos me servem de Guarda-de-Honra, quando, por acaso, preciso fazer alguma cavalgada heróica, semelhante às de Dom Antônio de Mariz ou às do Capitão-Mor de Dom José de Alencar!" (SUASSUNA, 2007, p. 384).

Dessa forma, exemplificamos a importância das Cavalhadas no imaginário do romance, com o fim de assegurar ser essa remanescência vigente em algumas regiões, configurando como forte dado cultural em determinadas manifestações no país. É conveniente observar ao longo do período medieval a junção do profano ao sagrado, já que em vários momentos durante o medievo, eles coexistiram nas mesmas representações e cenas. Em Suassuna, especialmente n'A Pedra do Reino, a fusão do sagrado e do profano é visível, pois pode ser reconhecida quando Quaderna cria uma atmosfera profana aliada ao teor religioso de seu relato. $\mathrm{O}$ fato religioso é recriado através da inserção do cômico durante o depoimento do narrador. Primeiramente Pedro Dinis Ferreira Quaderna divaga sobre a lembrança da cavalgada que traz de volta a Taperoá o primo Sinésio, este, por sua vez, constantemente associado à figura do santo.

\section{O sagrado e o profano: o riso residual}

Os episódios que enovelam Sinésio, o Rapaz-do-CavaloBranco são contados sob atmosfera sagrada, sobrenatural. Com efeito, o risível surge na medida em que o narrador conta seu memorial. O profano é pincelado a cada menção religiosa, seja em relação aos episódios nos quais Quaderna apresenta os preceitos de sua "Liturgia Católico-sertaneja", regada a vinho e mulheres; seja no tocante à paródia sebastianista, na pessoa do primo; ou referente às aparições de divindades alegorizadas ao longo da narrativa. $\mathrm{O}$ fragmento a seguir comprova o profano nos rituais "sagrados" praticados pelo mais destacado Rei do qual descende Quaderna:

https://periodicos.unifap.br/index.php/letras Macapá, v. 6, n. I, Io semestre, 2016. 


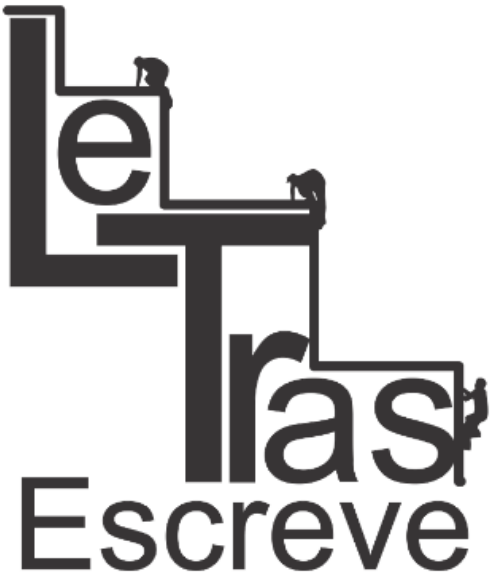

(ISSN 2238-8060)
Acontece que meu bisavô, o Infante Dom João FerreiraQuaderna, tinha seduzido e raptado, de uma só vez, as duas primas, a Infanta Josefa e a princesa Isabel, irmãs do Rei Dom João I, que abdicara. Meu bisavô era meio tarado, bastando dizer que, depois, quando já tinha sido coroado rei, instituiu, na Pedra do Reino, um ritual Católico-sertanejo, segundo o qual ele, Rei, era quem primeiro possuía as noivas, no dia do casamento, o que fazia, segundo explicava, "para inoculá-las com o Espírito Santo". Parece que ele só conseguia ser macho praticando, ao mesmo tempo, um sacrilégio e uma crueldade mas, então, depois de assim despertada pelo sangue e pela maldade, não havia quem contivesse mais sua potência. Pois bem: como o Catolicismo sertanejo da Pedra do Reino permitia a poligamia, Dom João Ferreira-Quaderna, o Execrável, chegou a ter o número sagrado de sete mulheres, entre as quais as mais importantes, mesmo, eram as duas Princesas irmãs, Josefa e Isabel, por serem de sangue real (SUASSUNA, 2007, p.74).

O fragmento é ilustrador do profano presente na Liturgia Católico-sertaneja associado ao sagrado. Dom João Ferreira, praticante de poligamia, desposa suas primas e também outras mulheres antes mesmo de seus maridos, com a desculpa de ser esse ato exigência dos rituais da Pedra do Reino. Em nossa literatura também ecoa o uso do burlesco associado ao sagrado a fim de provocar o riso, fato esse devedor medieval, já que o uso do profano em aliança com a atmosfera sacra constituiu recurso criativo nos tempos antigos e medievais, hoje aparecendo remanescente na literatura popular nordestina, da qual faz uso o romancista paraibano.

A inserção do profano no sagrado tratado na obra do autor se verifica por meio das oposições risível/sério das quais Suassuna faz uso no seu processo de construção artística, mesmo recurso ficcional presente na cultura popular do Nordeste, fonte em que bebe o dramaturgo. Ora, percebemos pela leitura dos folhetos nordestinos e pelos espetáculos populares encenados na região o caráter religioso dos temas associados às superstições, muitas vezes ao demoníaco, e ao riso, por isso refletido na escrita e na mentalidade do romance.

https://periodicos.unifap.br/index.php/letras

Macapá, v. 6, n. I, Io semestre, 2016. 
N'A Pedra do Reino, assim como foi na literatura medieval e está no percurso da formação do auto proposta por Câmara Cascudo, que também reconhece nessa forma dramática a miscelânea do sagrado e do profano, toda a ideologia oficial da Igreja, todos os ritos dessa instituição são descritos do ponto de vista cômico. Para referendar o argumento basta sublinhar a passagem do depoimento de Quaderna ao Juiz Corregedor, quando o narrador explica o surgimento de sua "Liturgia Católico-sertaneja":

$\mathrm{Na}$ Astrologia, eu já fora iniciado por meu Pai que, como redator do Almanaque do Cariri, era Mestre nos Arcanos do Tarô e dono da Chave da Cabala. Assim que tomei conhecimento dessas coisas, fundi num fogo só esses elementos dispersos, e descobri imediatamente que a nova Religião fundada por mim, o Catolicismo sertanejo, estava em harmonia absoluta com o programa da minha vida, influenciada, como sempre e em tudo, por Samuel e Clemente. Como Catolicismo, era uma religião bastante monárquica, cruzada e ibérica para satisfazer o primeiro; e como Sertaneja, era suficientemente popular e negro-tapuia para ser considerada com simpatia pelo segundo. Posso, então, concluir, dizendo a Vossa Excelência que foram esses os acontecimentos que me trouxeram à minha atual condição de Profeta da Igreja Católico-sertaneja e Príncipe de Sangue do Trono do Sertão do Brasil! (p. 169)

O elemento profano inserido no religioso, residualmente atualizado e recriado na ficção suassuniana, encontra-se também nas descrições dos rituais "litúrgicos" de Quaderna, "Pontífice, Rei e Profeta", quando este relata ao Juiz "Cabeça de Porco" o seu "banquete eucarístico":

Comecei então, como vinha dizendo, a comer ritualmente os nacos de carne de sol, misturando-os com a paçoca e evitando os entalos e engasgos da comida seca e salgada, gostosíssima, com deliciosos e grandes goles do meu Vinho Sertanejo da Malhada. Quando me fartei de carne assada e paçoca, terminando outra parte do ritual, voltei ao Altar, folheei o Livro do peregrino do Sertão e o Almanaque Astrológico, Zodiacal e Genealógico do Cariri, salmodiando de novo, nos seguintes termos: "Ó Adonai! Ó Onça Tapuia, Negra e Malhada do Divino do Sertão! Esta República dominada por Burgueses gordos é, sem dúvida, um grande mal para o Império do Sertão do Brasil! Ela pretende minar e desmoralizar o Povo da Onça Castanha e o nosso Catolicismo-sertanejo, esta obra-prima de Deus, religião mais perfeita e mais antiga do que o Catolicismo

https://periodicos.unifap.br/index.php/letras

Macapá, v. 6, n. I, Io semestre, 2016. 
Romano! Este, tem somente vinte séculos, enquanto a nossa sagrada Religião da Pedra do Reino foi fundada no Deserto sertanejo da Judéia, junto às Pedras do Reino do Sinai e do Tabor! (SUASSUNA, 2007, p. 553).

A passagem acima é um trecho de puro discurso residual, é confirmação de que tudo é resíduo do que já houve em tempos remotos. Quaderna ao citar, embora alegoricamente e para gerar o riso, que sua liturgia "é mais antiga do que o Catolicismo Romano, sendo fundada no Deserto da Judéia, junto às Pedras do Sinai e do Tabor", representa a longa duração da mentalidade coletiva. Para o narrador, sua liturgia é mais antiga do que vinte séculos de catolicismo romano, decorre da hibridação de povos permitindo que todas as formas culturais um dia se encontrem, trata-se de proximidade espacial e temporal, por isso residual.

A vinculação do sagrado ao profano de que faz uso Suassuna em sua narrativa é referente ao medievo, já que o cunho didático do teatro medieval; mais especificamente do auto, entrevisto pelas considerações de Câmara Cascudo e de Lígia Vassallo, desde o século XVI foi usado pelos padres jesuítas como poderoso elemento de catequese, ou seja, era arte dirigida ao povo a fim de evangelizar; o torna atemporal, pois o fato bíblico é visto como perene. Além disso, é também depositário de todos os extremos: o sublime e o grotesco, o elevado e o popular, o celeste e o cotidiano, o trágico e o cômico, o sagrado e o profano. Na narrativa de Suassuna, a mescla sacro/profano não tem caráter evangelizador como no medievo, mas, do mesmo modo, é procedimento criativo híbrido e formado de opostos, operando com as mesmas conotações medievais e antitéticas descritas acima.

No Romance da Pedra do Reino a fusão do sagrado e do profano é componente para o riso da narrativa. O sério e o religioso dos rituais católicos e do sebastianismo descritos durante o relato quadernesco são permeados de tom jocoso e de profano. Quaderna narra sua "demanda novelosa" a partir da esfera sagrada 


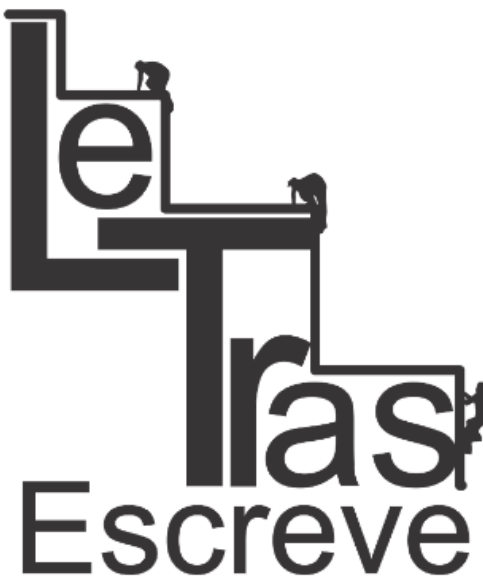

(ISSN 2238-8060) apresentando-nos um mito: uma saga familiar e o retorno do sebastianismo sob o viés da derrisão.

O aspecto risível da narrativa, embora aliado às descrições de sangrentas guerras e mediado pela figura de Dom Sebastião, já é percebido desde as primeiras páginas. Ao iniciar o memorial dirigido aos brasileiros, sem exceção, de modo a comover também e especialmente "os magistrados e soldados do Supremo Tribunal, toda essa raça ilustre que tem o poder de julgar e prender os outros", e os escritores brasileiros principalmente, aqueles "Poetasescrivães e Acadêmicos-fidalgos", Quaderna define sua narrativa como "um pedido de clemência, uma espécie de confissão geral e uma apelação".

Os leitores, interpelados pelo narrador constantemente pelo qualificativo de "nobres Senhores e belas Damas de peitos brandos", já percebem que o narrador argumentará para contar os infortúnios decorrentes do processo em que se vê envolvido, "a guisa de apelo e defesa", definindo-se como "modesto Cronista-Fidalgo, RapsodoAcadêmico e Poeta-Escrivão". Pedro Dinis Quaderna apresenta-nos seu romance como "uma terrível história de amor e de culpa; de sangue e de justiça; de sensualidade e violência; de enigma, de morte e disparate; de lutas nas estradas e combates nas Caatingas" (SUASSUNA, 2007, p. 35). Declara ser "Dom Pedro IV, O Decifrador, Rei do Quinto Império e do Quinto Naipe, Profeta da Igreja Católico-Sertaneja e pretendente ao trono do Império do Brasil" (SUASSUNA, 2007, p. 35). É decifrador por gostar de enigmas, adivinhas e astrologia; rei do Quinto Naipe, por ser apreciador do jogo de baralho; profeta, por criar uma liturgia cômica; e sua pretensão ao "Trono do Brasil" ocorre por meio da Literatura. A coroa desejada por Quaderna é a de escritor de uma "Obra Máxima", seu reinado acontecerá por meio de delírio e de sonho no momento de sua posse na Academia Brasileira de Letras.

O uso do sagrado pelo profano é latente no imaginário, na mentalidade coletiva da região brasileira retratada pelo escritor

https://periodicos.unifap.br/index.php/letras Macapá, v. 6, n. I, Io semestre, 2016. 


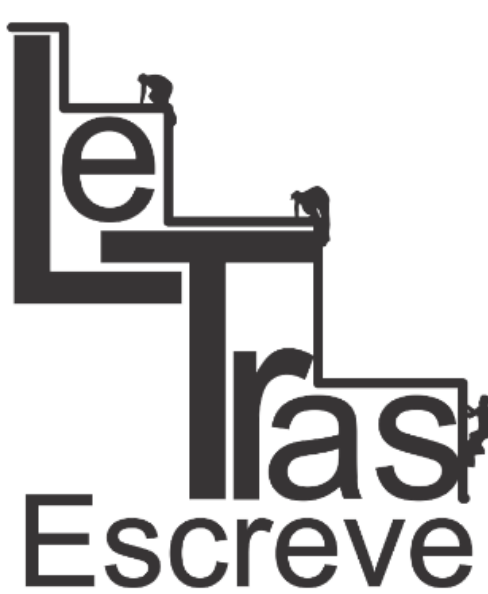

(ISSN 2238-8060) paraibano, basta lembrar os "causos" contados pelos sertanejos debaixo dos laranjais e dos alpendres das fazendas. Assim, os rituais de inversão parodística, embora intertextuais, permaneceram sob forma de resíduo, assumindo comportamento cristalizado, pois fazem referência ao plano mental, a uma postura comum assumida na Idade Média. Em A Pedra do Reino, os episódios bíblicos e cristãos não constituem apenas releitura parodística. Representam igualmente a forma de agir, e de pensar da sociedade nordestina, marcada pelo uso do sagrado em suas festividades e cultura.

Se o riso do romance associa o sério ao cômico, ele é repetidor inconsciente do medievo que usou o profano no sagrado para conseguir a risada do público, o qual, por sua vez, também é resíduo do riso dos antigos. Em literatura e cultura, tudo é dívida e recriação a cada novo "causo" contado. Diante de um texto tecido com fios memoriais e textuais alheios, resta-nos deixar as considerações finais a cargo de explicações hipotéticas. Os estudos e análises feitos até aqui servirão de meras tentativas. Não se esgotarão as abordagens e a obra ficará cristalizando significados, polindo os resíduos e descortinando as mentalidades.

\section{REFERÊNCIAS BIBLIOGRÁFICAS}

CAMPOS, Maximiano. "Posfácio". In: SUASSUNA, Ariano. Romance d'A Pedra do Reino e o Príncipe do Sangue do Vai-e-Volta - 9a ed. Rio de Janeiro: José Olímpio, 2007 a , p. 746

PONTES, Roberto. "Em torno de um resíduo: Santa Maria Egipcíaca". In: $2^{\circ}$ Colóquio do PPRLB -Relações Luso-Brasileiras; deslocamentos e permanências. Rio de Janeiro: Real Gabinete Português de Leitura, 2004. Versão eletrônica disponível em: www.realgabinete.com.br/coloquio/autor.asp?indice $=62$

SUASSUNA, Ariano. "Posfácio". In: MARINHEIRO, Elisabeth. A intertextualidade das formas simples. Rio de Janeiro: Gráfica Olímpica Editora LTDA, 1977, p. 181-182.

. Romance d"A Pedra do Reino e o Príncipe do Sangue do Vai-e-Volta. - 9a ed. - Rio de Janeiro: José Olympio, 2007.

Recebido em 02/02/2016. Aprovado em 14/03/2016.

https://periodicos.unifap.br/index.php/letras

Macapá, v. 6, n. I, Io semestre, 2016. 